\title{
Scaling up social innovation for sustainability: The roles of social enterprise capabilities
}

\author{
Noor Raihani Zainola ${ }^{\mathrm{a}}$ Fakhrul Anwar Zainol ${ }^{\mathrm{b}}$, Yahaya Ibrahim ${ }^{\mathrm{c}}$ and Asyraf Afthanorhan
}

${ }^{a}$ Faculty of Entrepreneurship and Business, Universiti Malaysia Kelantan, Locked Bag 36, Pengkalan Chepa, 16100 Kota Bharu, Kelantan, Malaysia

${ }^{b}$ Faculty of Economics and Management Sciences, Universiti Sultan Zainal Abidin, Gong Badak Campus, 21300 Kuala Nerus, Terengganu, Malaysia

${ }^{c}$ Faculty of Applied Social Sciences, Universiti Sultan Zainal Abidin, Gong Badak Campus, 21300 Kuala Nerus, Terengganu, Malaysia

\section{H R O N I C L E}

Article history:

Received: October 18, 2018

Received in revised format: No-

vember 29, 2018

Accepted: December 7, 2018

Available online:

December 11, 2018

Keywords:

Social enterprise capabilities

Scaling

Social innovation

Social problem

\section{A B S T R A C T}

The scaling of social innovation is an important issue in social enterprises for sustainability. The scenario is due to the social enterprise capabilities to ensure the social program's impact on society to become wider and deeper. Thus, social innovation helps to identify the social problems and target actions to address the social complex problems by social enterprise capabilities. This study investigates the factors of social enterprise capabilities in enhancing social innovation for sustainability and for eliminating the social barriers. In addition, the study discusses the relationship between social enterprise capabilities to scale social innovation. The study uses cross-sectional design and collects the necessary data from 136 social enterprises in Malaysia for the survey. The findings show that social enterprise capabilities for earning generation, replicating, and stimulating had a positive relationship with scaling social innovation when the level of significance was 0.05 . Accordingly, the social enterprise owners are required to improve their capabilities to reach a higher scale of social innovation for growth and sustainability.

(C) 2019 by the authors; licensee Growing Science, Canada

\section{Introduction}

The social aspect is often regarded as the responsibility of the government sector and non-government organizations, while it requires all parties to achieve the social problem (Ishak \& Omar, 2015). Although the social sectors such as Tandemic and Social Enterprise Alliance have actively generated awareness and supported the society in Malaysia, these initiatives alone do not to seem sufficient to fully realize the potential of this sector (Nicholls, 2010; Mulgan, 2015; Malaysian Social Enterprise Blueprint, 2015). The sector requires all parties' involvement including community, government, private and public sectors for the social enterprise growth and development (Austin et al., 2006; Zahra et al., 2009; Defourny \& Nyssens, 2010; Bjerke, 2013). Upon recognizing the potential of social enterprises, the Malaysian government gives a mandate to Malaysian Global Innovation and Creativity Centre (MaGIC) of Social Entrepreneurship to develop the social enterprise sector in Malaysia. To effectively support this effort, the government allocates RM20 Million to set up a social entrepreneur-

\footnotetext{
* Corresponding author.

E-mail address: fakhrulanwar@unisza.edu.my (F. A. Zainol)

(C) 2019 by the authors; licensee Growing Science, Canada doi: $10.5267 /$ j.msl.2018.12.005
} 
ship unit to catalyze impact-driven enterprises, which is known as Malaysian Social Enterprise Blueprint. This effort is due to the government vision to achieve 2020 target and to become a high-income nation as a regional leader for a people-centric economy that is sustainable and equitable (Economic Planning Unit, 2016). This approach means that more focus and resources are being allocated to deliver public services that are coherent with the public's increasing demand for access to quality of service. A people-centric approach also allows for innovation within the service to remain relevant and useful (Social Enterprise National Survey, 2015). Thus, social entrepreneurship is a way to solve the social problem with the innovative business model (Agrawal et al., 2013; Ishak et al., 2015).

In Malaysia, social enterprises are divided into two characteristics provided by MaGic (2015) with social mission and business model supported by characteristics which are inclusive, transparent, and accountable to shareholders and beneficiaries. For the first characteristics, through the social mission, social enterprises solve a legitimate issue typically neglected by the public and private sectors, with the specific target group of beneficiaries, typically those who are not deserved by the market. While, business model allows social enterprises to generate income and profit by selling products or services demanded by the market, such as, training, employing or consulting underserved people to create something that is useful in the market. The second characteristics provide fair compensation and returns, responsible and transparent, inclusive equity and just governance, where all artisans are paid a monthly salary associated with EPF and SOCSO contribution. The development of the social enterprise sector in Malaysia is challenging. In comparison with the other countries, this sector has successfully implemented a national blueprint, master plan or strategy such as, Thailand, Vietnam, China, United State, Canada, South Korea and the United Kingdom to champion the growth of social enterprises (Euncheong, 2014; Mirella, 2011). Even though there is an increasing number of supporting intermediary organizations for social enterprises in Malaysia from 2015 to 2018, the number is still low compared with the other countries, which have the legal recognition of constitution of social enterprise (MaGIC, 2015).

Social enterprises provide some perfect opportunities to invest strategically and to ensure the development of a sector that will transform the nation's economy to the one that is more equitable and sustainable (Kelsey, 2016). Furthermore, few studies conducted on international social enterprise have taken mostly a local, regional or national point of view and not global perspective (Marshall, 2011). For example, Tukamushaba et al. (2011) focused on social entrepreneurship in Ugandan context, Weerawarden and Mort (2006) in Australia perspectives, Eunchong (2014) in Korea context, while Madill et al. (2010) focused on Canadian social enterprises. This study, therefore, intends to investigate the relationship between social enterprise capabilities to scale social innovation among social enterprises in the Malaysian context.

\section{Literature Review}

This study focuses on nine key capabilities of social enterprise capabilities, as suggested by Bloom et al. (2010) and Burke-Litwin (1992), while social innovation constructs are provided by Scott and Bruce (1994). The nine keys for capabilities are Staffing, Communicating, Alliance-Building, Lobbying, Earning Generation, Replicating, Stimulating Market Forces, Systems and Structure.

Staffing is associated with the effectiveness of the organization at filling labor requirements and managerial posts, with the person who fulfills the needed positions, no matter they are paid or volunteers (Bloom et al., 2010). According to Becker (1964), the social enterprises would have little difficulty to meet up the positions with the competent person, which means that those social enterprises must have the capabilities to acquire, develop and maintain the necessary human capital. The majority of social enterprises are small and face constrained for their resources, especially to pay the market rate to employees (Bridgstock et al., 2010). Thus, staffing issue brings challenges to the social enterprise's management in effectively recruiting and developing human capital through a combination of an employee 
and volunteer labor (Battilana et al., 2010). The researcher such as Battilana et al. (2010) and Haugh (2007) found that the social components of the dual mission act as the instrumental in enabling social enterprise leaders to recruit and mobilize employees' efforts. The combination of enterprise and social innovation are repeatedly cited as a motivating force that provides employees with the intrinsic rewards the job satisfaction, as well as contributing to social community impact (Bacchiega et al., 2001). The social enterprises should be able to better position to a successful scale for its social innovation. This study, therefore, formulates the following hypothesis:

$H_{l}$. Staffing has a positive relationship with the scaling of social innovation.

Communicating is the term is referred for the effectiveness of an organization to persuade key stakeholders to make suitable changes (Bloom et al., 2010). The change strategy helps the social enterprises create favorable attitudes or behaviors towards the organization's programs among the social enterprise's stakeholders including beneficiaries, volunteers/employees, partners, consumers, or donors (Bloom et al., 2009). The social enterprise also used the assertive or proactive marketing strategy of supplication through communicating the dependence of those social enterprises and their beneficiaries (Mohammed et al., 1999). As mentioned by Smith et al. (2010) the social enterprise's leader communicate with the key stakeholders and help them understand about their social missions that create sustainability for a long time. Thus, social innovations have come into social development plans in social enterprises for sustainability. It is difficult for the social enterprises to survive for the long term with other organizations without innovations (Konda et al., 2014). In addition, the effectiveness of the social enterprise's capabilities of communication allows them for growth and scaling social innovation (Bloom et al., 2009). Based on the discussion above, the following hypothesis is posited:

$H_{2}$. Communication has a positive relationship with the scaling social innovation.

Alliance building is associated with the social enterprises, which forged partnerships, coalitions, joint ventures, and other linkages to bring about desired social changes. The social enterprises do things by seeking the benefits of unified efforts (Bloom et al., 2010). The successful social entrepreneurs will offer everyone's contribution for the scaling efforts of social innovation (Kelsey, 2016). To build the alliances we need social entrepreneur to search for the teams with common goals (Bloom et al., 2009). Some social entrepreneurs may find the alliances to be quite difficult with some organizations having conflicting objectives (Dees, 2010; Sharma, 2017). Thus, forming a good relationship with a great partner, which have many specialties and skills like what the organizations need can increase the effectiveness of the social enterprise's capabilities, as well as the scale for social innovation (Bloom et al., 2010). Based on the above discussion, the study proposes the following,

$H_{3}$. Alliance building has a positive relationship with the scaling social innovation.

Lobbying is referred to the effectiveness of an organization to advocate for the government actions that may work in its favor, for example, getting to the courts, administrative agencies, legislators, and government leaders (Bloom et al., 2010). Lobbying can also attract funding and can help social enterprises build relationships with like-minded groups and legislators (Bacq et al., 2011). According to Crouch (2006), the political influence with social enterprises and environmental responsibility is highly complex. It is due to drawing of a clear distinction between the profit-making activities and external governmental regulations. In this case, the social enterprise's capability of lobbying is focused on the development of the political capital associated with resources and powers by linking social society to the political system (Sorenson, 2003). Thus, lobbying can be used to increase scale social impact, as a result of the skill social enterprises leader at the development of political capital (Bloom et al., 2010). This study, therefore, formulates the following hypothesis:

$H_{4}$. Lobbying has a positive relationship with the scaling social innovation. 
Earning generation is referred to social enterprise effectiveness in generating a stream of revenue that exceeds its expenses, such as paying bills (electric/water) and funding its activities (Bloom et al., 2010). According to the Social Enterprise National Survey (2015) most of the social enterprise's revenue is generated from their sales, which demonstrate that those organizations have a demand and market for delivery of products and services. Moreover, Borzaga (2015) noted that some of the social enterprises depend on personal donations, grants, and fundraising to ensure their sustainability. In addition, Bloom et al. (2010) agreed that earning generations come from the earned income efforts through selling or promoting on a website, donations, grants and sponsorships. These efforts will have their social impacts towards social innovation to increase the effectiveness of social enterprise capabilities. Hence, social enterprises pursue projects under the constraint of efficiency for seeking profit for distribution to target groups, paying bills, and investment towards the growth of the organizations (Becchetti et al., 2011). This study, therefore, postulates that:

$H_{5}$. Earning generation has a positive relationship with the scaling social innovation.

Replicating refers to how effectively the social enterprise can reproduce the programs, activities, and initiatives for making some changes (Bloom et al., 2010). According to Bloom et al. (2010), the services, programs and all the related efforts of the social enterprise could be copied, reused or extended without losing quality, training, contracting, and other tools to ensure quality control. Ahlert et al. (2008) noted that the lack of the control mechanism for the original social enterprise lead to some disadvantages for the organization when it leads to quality loss. Thus, open source approaches are more appropriate for social enterprises because they have the primary goal of increasing their social innovation and thus focus mainly on value creation for society (Santos, 2009). According to Dees et al. (2004) the social enterprise makes the social innovation available by providing information, technical assistant and training offered to others who are interested in replicating the approach (programs). Thus, growth and successful scaling require replicating, and formalization to be reviewed continuously and adapted to the change of the social enterprise conditions (Morris et al., 2011). In line with earlier studies, this study hypothesizes the following:

H6. Replicating has a positive relationship with the scaling social innovation.

Stimulating market forces is the effectiveness of social enterprise in creating the incentives that encourage people or organizations to pursue private interests while serving the public good (Bloom et al., 2009). To effectively stimulate the market, the social enterprise creates a market for offering products and services, for example, microfinance, less price for health remedies or farming equipment, and food discount. Social enterprise might combine unearned income and commercial revenue or rely on trading income to meet social objectives. For examples, social enterprises offer a fair price for the supply production and implement sustainable farming practices (Davies et al., 2010). Thus, stimulating market forces lead to significant social innovation to change or help social problem among society. For instances, providing a micro-loan to borrowers (poor people) and small businesses, create a job for the unemployed, and distribute food for the needed (Dees et al., 2004). This effort will reflects the economic incentives that motivate people's behavior (Bloom et al., 2010). Based on the discussion above, the following hypothesis is posited:

$H_{7}$. Stimulating market forces have a positive relationship to the scaling social innovation

Structure does not refer to a hierarchical structure only, but to the functional structure that focused on responsibility, authority, communication, and decision-making to ensure that the social mission and strategy is well implemented (Burke et al., 1992). Thus, the structure is to find out how the social enterprise's leader carries out the organization's strategies for growth and influence performance (Venkatraman, 1985; Pruett, 2013). Specific structural components interact organizational strategies and impact social innovation or performance of social enterprise both new and established organizations (Sack, 2002). According to Mintzberg (1973) structure is viewed as interaction and transmission variables that help to realize organizational goals. The structure can impact the ability of organizations to 
diffuse social innovations, which often affect organizations success (Kaplan et al., 2005). Also, the structure for the goal should be aligned to reduce conflicts, in order to find individuals with an appropriate mindset of social enterprises that focused on the social innovation as value creation, as well as financial sustainability (Heinecke et al., 2012; Stumbitz, 2013). Therefore, the following hypothesis is proposed:

H8. Structure has a positive relationship with the scaling social innovation.

Systems are referred to the standardized types of policies and procedures that develop reward and control, information, performance appraisal, goals and budget as provided by Burke et al., (1992). The review of scaling for the system has been suggested in the previous literature by numerous researchers such as Bradach (2003), Alvord et al., (2004), France et al., (2006); Sezgi et al., (2010) as an important internal organizational factor for social innovation. This scenario is due to the systems function to facilitate the coordination of internal resources needed for scaling (Sezgi et al., 2010). Weber et al. (2012) further expanded on the idea by including the crucial of the systems happened around goal setting, monitoring, evaluating, reporting and budgeting in the social organizations to achieve social innovation as their mission. Therefore, the social enterprise requires to blend the value of the system to seek the social innovation that involves economic and social mission, growth, and sustainability to avoid any constrained (Hashmi, 2010). Therefore, this study suggested the following hypothesis:

$H_{9}$. System has a positive relationship with the scaling social innovation.

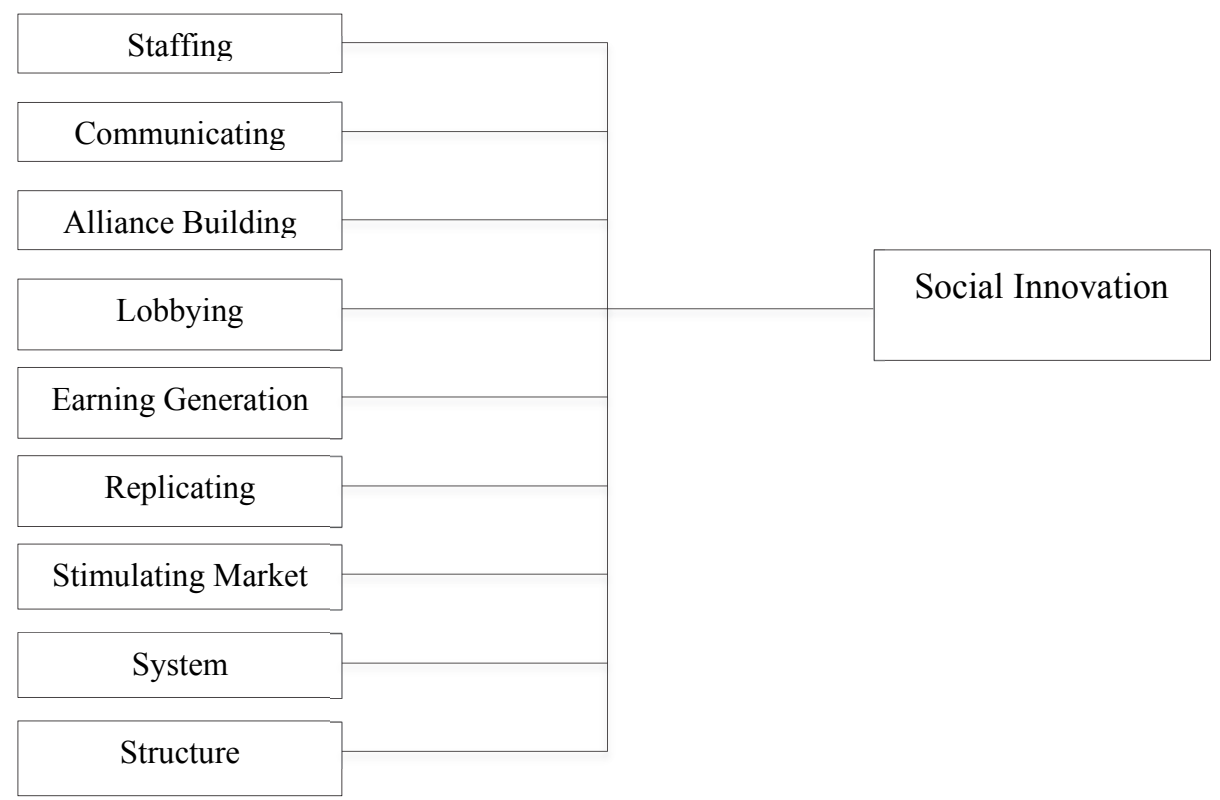

\section{Research Methodology}

Fig. 1. Theoretical Framework

In this study, a cross-sectional design was used to explain the factors of social enterprise capabilities to scale social innovation, which contributes to the social sector. The data were collected from social enterprises leader or partner in Malaysia by using purposive sampling technique. A total of 136 social enterprise leaders from the sampling frame who operate social enterprises (based on study criteria) in Malaysia were requested to fill up the questionnaire given. All the respondents involved in different types of social organization with different social innovation programs. The questionnaire was designed using simple, clear, and unbiased wordings to ensure the respondents comprehend the questions and to provide answers undoubtedly. The questionnaire was divided into several sections that required the respondents to indicate on a 5-point Likert scale ranging from 1 (strongly disagree) to 5 (strongly agree) to which they agreed with the statement described their social enterprises. This study used the variancebased structural equation modeling, which is the partial least squares (PLS). This method was chosen 
because it allows for the estimation of measurements and path coefficients, simultaneously. Also, the result of the analysis was suitable to use PLS as suggested by Hair et al., (2013).

\section{Findings}

\subsection{Construct Validity and Reliability Analysis}

In assessing the measurement model, the validity and reliability test were used to examine the quality of the measurement model. In this study, the analysis of reliability is conducted by Cronbach Alpha, Joreskog Rho and Dijktsra-Henseler. This study uses all the reliabilities test to produce a robust result. Meanwhile, the validity can be divided into two parts that are convergent and discriminant validity (AlMhasnah et al. 2018). The convergent validity can be represented by the assessment of Average Variance Extracted (AVE) and discriminant validity can be assessed by the two approaches: Fornell and Larcker and Heterotrait-Monotrait Ratio (HTMT) approach (Afthanorhan et al., 2018). Among of these approaches, the HTMT is recommended across fields since it already justified by the prominent researchers about its powerful.

\subsubsection{Reliability}

It is observed that all the variables for staffing, communicating, alliance building, lobbying, earning generation, replicating, stimulating, structure, systems and social innovation are reliable since Cronbach's alpha $(\alpha)$ for all of them are more than 0.7 . Also, to make sure that all constructs are reliable for this study, this study used the analysis Dijkstra-Henseler rho and Joreskog rho. Joreskog rho actually can be known as composite reliability which is popular in structural equation modeling technique. The results produced from the threshold methods are achieved at least 0.70 . Table 1 show the reliability results for all items are reliable since they achieved the minimum level of Dijkstra-Henseler rho, Joreskog rho and Cronbach Alpha.

\section{Table 1}

Construct Reliability

\begin{tabular}{lccc}
\hline Construct & Dijkstra-Henseler's rho $\left(\rho_{\mathrm{A}}\right)$ & Jöreskog's rho $\left(\rho_{\mathrm{c}}\right)$ & Cronbach's alpha $(\alpha)$ \\
\hline Staffing & 0.8897 & 0.9149 & 0.8883 \\
Communicating & 0.8856 & 0.9118 & 0.8794 \\
Alliance Building & 0.8824 & 0.9137 & 0.8819 \\
Lobbying & 0.8822 & 0.9118 & 0.8793 \\
Earning Generations & 0.8817 & 0.9110 & 0.8780 \\
Replicating & 0.8783 & 0.9041 & 0.8730 \\
Stimulating Market & 0.8514 & 0.8933 & 0.8506 \\
Structure & 0.8446 & 0.8934 & 0.8413 \\
Systems & 0.8631 & 0.8947 & 0.8589 \\
Social Innovation & 0.9527 & 0.9569 & 0.9512 \\
\hline
\end{tabular}

\subsubsection{Convergent Validity}

The convergent validity can be assessed using Average Variance Extracted (AVE). The minimum cutoff for AVE is 0.50 as stated by Awang (2015), Hair at al. (2017), and Afthanorhan et al. (2019) which indicates sufficient convergent validity. Table 2 shows the AVE result is more than 0.5 .

Table 2

Average Variance Extracted (AVE)

\begin{tabular}{lclc}
\hline Construct & Average variance extracted (AVE) & Construct & Average variance extracted \\
\hline Staffing & 0.6422 & Replicating & 0.6114 \\
Communicating & 0.6741 & Stimulating Market & 0.6261 \\
Alliance Building & 0.6792 & Structure & 0.6770 \\
Lobbying & 0.6740 & Systems & 0.5866 \\
Earning Generations & 0.6720 & Social Innovation & 0.6311 \\
\hline
\end{tabular}




\subsubsection{Discriminant Validity}

The Heterotrait-Monotrait ratio (HTMT) is an estimation of the correlation among the constructs. According to Henseler et al. (2016) and Henseler et al. (2015), the Heterotrait Monotrait method is satisfied when the value of construct correlations is below than 0.90 . Therefore, this study concluded that there was no evidence of a lack of discriminant validity and all the constructs meet the criteria. Table 3 shows the result for the discriminant validity.

Table 3

Discriminant Validity (HTMT)

\begin{tabular}{|c|c|c|c|c|c|c|c|c|c|}
\hline Construct & St & Co & Al-B & Lo & Ea-G & $\mathbf{R e}$ & Sti & Str & Sys \\
\hline \multicolumn{10}{|l|}{ Staffing } \\
\hline Communicating & 0.6257 & & & & & & & & \\
\hline Alliance building & 0.5729 & 0.571 & & & & & & & \\
\hline Lobbying & 0.6104 & 0.6265 & 0.6345 & & & & & & \\
\hline Earning generations & 0.701 & 0.5733 & 0.6101 & 0.7089 & & & & & \\
\hline Replicating & 0.6554 & 0.6354 & 0.6035 & 0.6266 & 0.6187 & & & & \\
\hline Stimulating Market forces & 0.6735 & 0.6264 & 0.6638 & 0.6925 & 0.6778 & 0.7156 & & & \\
\hline Structure & 0.5631 & 0.5305 & 0.5131 & 0.5071 & 0.6167 & 0.6093 & 0.6289 & & \\
\hline Systems & 0.631 & 0.5952 & 0.6733 & 0.6107 & 0.6667 & 0.559 & 0.5559 & 0.4899 & \\
\hline Social innovation & 0.5543 & 0.5162 & 0.5808 & 0.5936 & 0.6289 & 0.641 & 0.7043 & 0.5242 & 0.5302 \\
\hline
\end{tabular}

Notes: St: Staffing; Co: Communicating; Al-B: Alliance building; Lo: Lobbying; Ea-G: Earning generations; Re: Replicating; Sti: Stimulating market forces; Str: Structure; Sys: System; SI: Social Innovation

\subsection{Path Coefficient}

According to Hair et al. (2014), the signs of the path coefficients must follow the theoretical foundation of direction of the path, whereas bootstrapping procedure was performed to measure the significance of the path coefficients by evaluating the observed t-value and also $95 \%$ bootstrap confidence interval (Ringle et al., 2013; Hair et al., 2017).

Table 4

Path Coefficient

\begin{tabular}{lccccc}
\hline \multicolumn{1}{c}{ Effect } & Beta & Mean & SE & t-value & p-value \\
\hline Staffing $\rightarrow$ SI & 0.0003 & 0.0037 & 0.0748 & 0.0039 & 0.9969 \\
Communicating $\rightarrow$ SI & 0.0026 & 0.0056 & 0.0886 & 0.0288 & 0.9770 \\
Alliance Building $\rightarrow$ SI & 0.0951 & 0.0916 & 0.0910 & 1.0455 & 0.2958 \\
Lobbying $\rightarrow$ SI & 0.0774 & 0.0788 & 0.0949 & 0.8150 & 0.4151 \\
Earning Generations $\rightarrow$ SI & 0.1590 & 0.1574 & 0.0822 & $\mathbf{1 . 9 6 3 9}$ & $\mathbf{0 . 0 4 3 2}$ \\
Replicating Scale $\rightarrow$ SI & 0.1881 & 0.1834 & 0.0899 & $\mathbf{2 . 0 9 2 5}$ & $\mathbf{0 . 0 3 6 4}$ \\
Stimulating Market $\rightarrow$ SI & 0.2589 & 0.2559 & 0.0920 & $\mathbf{2 . 8 1 5 0}$ & $\mathbf{0 . 0 0 4 9}$ \\
Structure $\rightarrow$ SI & 0.0450 & 0.0460 & 0.0676 & 0.6655 & 0.5058 \\
Systems $\rightarrow$ SI & 0.0486 & 0.0523 & 0.0860 & 0.5648 & 0.5722 \\
\hline
\end{tabular}

Table 4 shows the results of the path coefficients that indicated that Earning Generation $\rightarrow$ Social Innovation (SI), Replicating $\rightarrow$ Social Innovation (SI), and Stimulating $\rightarrow$ Social Innovation (SI) were significant for at $p$-value of 0.000 since the observed $t$-value for each path coefficient was significance with critical value of t-statistics (i.e. Observed t-value $>1.96$ ), whereas other paths were found to be in significant since the observed t-values were less than critical value of $t$-statistics (Critical value $=1.96$ ). Therefore, Earning Generation $\rightarrow$ Social Innovation $(\widehat{\beta}=0.1590, t=1.9639, p<0.05)$; Replicating $\rightarrow$ Social Innovation $(\widehat{\beta}=0.1881, t=2.0925, p<0.05)$; and Stimulating $\rightarrow$ Social Innovation $(\widehat{\beta}=$ $0.2589, t=2.8150, p<0.05)$, indicate positive significant effect for direct effect.

\section{Discussion and Conclusion}

According to the objectives, the findings of the study implied that social enterprise capabilities had a positive relationship with scaling social innovation, which are earning generation, replicating, and stimulating. The $p$-value for the path coefficient indicated that social enterprise capabilities had a significant effect on social innovation among social enterprises in Malaysia. Findings of this study also revealed 
that earning generation, replicating, and stimulating had a positive relationship with scaling social innovation, which would improve the performance of the social enterprises in Malaysia. Therefore, the contribution of this study allows the related parties to improve the understanding of the social enterprise capabilities on social innovation. Thus, the social enterprise leaders should improve their capabilities to successfully implement their social innovation. This is due to the importance of the social enterprise's capabilities as it combined different forms of capital to develop, maintain, and create in scaling social innovation. These different forms of capital represent the potential structures and constraints available to the social enterprise. For examples, social enterprises capabilities such as replicating combine with alliance building will give an idea and more impact on social innovation (Gillis, 2011). Each of the capabilities plays a vital and unique role in social organizations towards growth and sustainability. These capabilities will work together to increase the success of social innovation based on path coefficient results that show Earning Generation $\rightarrow$ Social Innovation $\quad(\widehat{\beta}=0.1590, t=1.9639, p<0.05)$; Replicating $\rightarrow$ Social Innovation $(\widehat{\beta}=0.1881, t=2.0925, p<0.05)$; and Stimulating $\rightarrow$ Social Innovation $(\widehat{\beta}=0.2589, t=2.8150, p<0.05)$, which indicate positive significant effect for direct effect. Even though social enterprises is still in infancy stage, the findings of this survey will help to address the problem in innovation way and help social entrepreneurs understand the determinants of scaling social impact towards organizations growth (strengths and weaknesses). Also, social innovation is a way to solve social problems more effectively by combining the resources and capabilities that lead to the change of productivity.

\section{Suggestion for Future Research}

This study was exploratory and subject to several limitations that influence the findings. First, the data collection was limited to only the selected social entrepreneurs. Therefore, the future study could generalize the results to different context, culture, and industries. Also, the factors such as time and resource constraints caused the small sample size of the study, which was only 136 respondents in Malaysia from the different districts. In other words, the respondents did not cover all districts in Malaysia. Furthermore, this study applied a cross-sectional design and required a longitudinal study to be validated in the future study of social enterprises. Finally, there is a need for further research in comparing these findings with other states or countries, such as cross-cultural research to get a more robust result.

\section{Acknowledgement}

The authors would like to thank Universiti Malaysia Kelantan, Malaysia and Ministry of Higher Education in Malaysia for the support and fund in completing this survey.

\section{References}

Afthanorhan, A., Awang, Z., Rashid, N., Foziah, H., \& Ghazali, P. (2019). Assessing the effects of service quality on customer satisfaction. Management Science Letters, 9(1), 13-24.

Afthanorhan, A., Awang, Z., Salleh, F., Ghazali, P., \& Rashid, N. (2018). The effect of product quality, medical price and staff skills on patient loyalty via cultural impact in medical tourism. Management Science Letters, 8(12), 14211424.

Agrawal, A., \& Hockerts, K. (2013). Institutional theory as a framework for practitioners of social entrepreneurship', in T Osburg \& R Schmidpeter (eds), Social Innovation, Springer, Berlin Heidelberg, 119-29.

Ahlert, D., Ahlert, M., Duon Dinh, H. V., Fleisch, H., Heußler, T., Kilee, L. \& Meuter, J. (2008). Social franchising: A way of systematic replication to increase social impact.

AL-Mhasnah, A., Salleh, F., Afthanorhan, A., \& Ghazali, P. (2018). The relationship between services quality and customer satisfaction among Jordanian healthcare sector. Management Science Letters, 8(12), 1413-1420.

Alvord, S. H., Brown, D. L., \& Letts, C. W. (2004). Social entrepreneurship and societal transformation: an exploratory study. Journal of Applied Behavioral Science, 40, 260-282.

Austin, J., Stevenson, H., \& Wei-Skillern, J. (2006). Social and commercial entrepreneurship: same, different or both?, Entrepreneurship Theory and Practice, 30, 1-22.

Awang, Z. (2015). SEM made simple: A gentle approach to learning Structural Equation Modeling. MPWS Rich Publication. 
Bacchiega, A., \& Borzaga, C. (2001). Social enterprises as incentive structures: an economic analysis. In Borzaga, C. and Defourny, J. (eds), The Emergence of Social Enterprise. London: Routledge, 273-294.

Bacq, S., \& Janssen, F. (2011). The multiple faces of social entrepreneurship: A review of definitional issues based on geographical and thematic criteria. Entrepreneurship and Regional Development, 23(5-6), 373-403.

Battilana, J., \& Dorado, S. (2010). Building sustainable hybrid organizations: the case of commercial microfinance organizations. Academy of Management Journal, 53, 1419-1440.

Becchetti, L., Bruni, L., \& Zamagni, S. (2011). Microeconomia: scelte, relazioni, economia civile. Bologna: il Mulino.

Becker, G.S., 1964. Human capital: a theoretical and empirical analysis with special reference to education. Chicago, IL: University of Chicago Press.

Bjerke, B. (2013). About Entrepreneurship. UK: Edward Elgar Pub.

Bloom, P. N., \& Skloot, E., (2010). Scaling social impact: New thinking. Springer.

Bloom, P. N., \& Chatterji, A. K. (2009). Scaling social entrepreneurial impact. California Management Review, 51(3), 114-133.

Borzaga, C. (2015). Why social enterprises are asking to be multi-stakeholderand deliberative: An explanation around the costs of exclusion.

Bradach, J. (2003). Going to scale: the challenge of replicating social programs. Stanford Social Innovation Review, $1,18-25$.

Bridgstock, R., Lettice, F.M., Özbilgin, M.F. and Tatli, A. (2010). Diversity management for innovation in social enterprises in the UK. Entrepreneurship \& Regional Development, 22, 557-574.

Burke, W. W., \& Litwin, G. H. (1992). A causal model of organizational performance and change. Journal of Management, 18(3), 523-545.

Crouch, C. (2006). Modelling the firm in its market and organizational environment: Methodologies for studying corporate social responsibility. Organization Studies, 27(10), 1533-1551.

Davies, I. A., Doherty, B., \& Knox, S. (2010). The rise and stall of a fair trade pioneer: the cafédirect story. Journal of Business Ethics, 92, 127-147.

Dees, J. G. (2010). Creating large-scale change: Not 'can' but 'how'. What Matters, 04-06.

Dees, J. G., Anderson, B. B., \& Wei-Skillern, J. (2004). Scaling social impact. Stanford Social Innovation Review, 1(4), 24-32.

Defourny, J., \& Nyssens, M. (2010). Conceptions of social enterprise and social entrepreneurship in Europe and the United States: convergences and divergences. Journal of Social Entrepreneurship, 1, 32-53.

Malaysian Economic Planning Unit. (2016).

Eunchong, L. (2014). Examining the sustainability of social enterprise in contemporary Korea.

France, L. S., Lee, M., Green, R., Kvaternick, J., Robinson, A., \& Alarcon, I. (2006). Scaling capacities: supports for growing impact.

Hair Jr, J. F., Sarstedt, M., Ringle, C. M., \& Gudergan, S. P. (2017). Advanced issues in partial least squares structural equation modeling. SAGE Publications.

Hair Jr, J. F., Sarstedt, M., Hopkins, L., \& G. Kuppelwieser, V. (2014). Partial least squares structural equation modeling (PLS-SEM): An emerging tool in business research. European Business Review, 26(2), 106-121.

Hair, J. F., Hult, G. T. M., Ringle, C. M., \& Sarstedt, M. (2013). A primer on partial least squares structural equation modeling (PLS-SEM). Sage, Thousand Oaks.

Hashmi, A. M. (2010). Analysis of green financial markets. Journal of Business \& Economic Research, 8(1), 65-69.

Haugh, H. (2007). Community-led social venture creation. Entrepreneurship Theory and Practice, 31, $161-182$.

Heinecke, A., \& Mayer, J. (2012). Strategies for Scaling in Social Entrepreneurship. In: Volkmann C., Tokarski K., Ernst K. (eds) Social Entrepreneurship and Social Business. Gabler Verlag.

Henseler, J., Hubona, G., \& Ray, P. A. (2016). Using PLS path modeling in new technology research: updated guidelines. Industrial Management \& Data Systems, 116(1), 2-20.

Henseler, J., Ringle, C. M., \& Sarstedt, M. (2015). A new criterion for assessing discriminant validity in variancebased structural equation modeling. Journal of the Academy of Marketing Science, 43(1), 115-135.

Ishak, S., \& Omar, C. A. R. (2015). Social Entrepreneurship as an Innovative Approach towards Transformation of Social Society: Malaysian Case Study.

Kaplan, S. N., \& Schoar, A. (2005). Private equity returns: Persistence and capital flows. Journal of Finance, 60, $1791-1823$

Kelsey, E. R. (2016). A practical framework for the scaling of social enterprise across developed and developing economies.

Konda, I., Starc, J., \& Rodica, B. (2014). Social Innovations: The Way to Sustainable Development. International Scientific Conference.

Madill, J., Brouard, F., \& Hebb, T. (2010). Canadian social enterprises: An empirical exploration of social transformation, financial self-sufficiency, and innovation. Journal of Non-Profit \& Public Sector Marketing, 22(2), 135151. 
MaGic. (2015). State of Social Enterprise in Malaysia 2014-2015. Malaysian Global Innovation and Creativity Centre (MaGic) Social Entrepreneurship.

Malaysian Social Enterprise Blueprint. (2015). Retrieved from www.se.mymagic.my On 15 February 2018.

Marshall, R. (2011). Conceptualizing the international for-profit social entrepreneur. Journal of Business Ethics, 98(2), 183-198.

Mohammed, A., Gardner, W., \& Paolillo, J. (1999). A taxonomy of organizational impression management tactics. Advances in Competitiveness Research, 7(7), 108-130.

Morris, M. H., Webb, J. W., \& Franklin, R. J. (2011). Understanding the manifestation of entrepreneurial orientation in the nonprofit context. Entrepreneurship: Theory and Practice, 947-972.

Mintzberg, H. (1973). Strategy in three modes. California Management Review, 16, 44-58.

Mirella, L. (2011). Branding the social enterprise sector of Finland: The social entrepreneur perspective.

Mulgan, G. (2015). Forword: the study of social innovation - Theory, Practice and Progress. In: Nicholls, Alex/ Simon, Julie/ Gabriel, Madeleine (Eds.): New Frontiers in Social Innovation Research. Houndmills, Basingstoke, Hampshire: Palgrave Macmillan, pp. $\mathrm{x}$-xx.

Nicholls, A. (2010). The institutionalization of social investment: the interplay of investment logics and investor rationalities. Journal of Social Entrepreneurship, 1, 70-100.

Pruett, M. M. (2013). Instructional coaching: Leadership styles and practices.

Ringle, C. M., Sarstedt, M., Schlittgen, R., \& Taylor, C. R. (2013). PLS path modeling and evolutionary segmentation. Journal of Business Research, 66(9), 1318-1324.

Sack, W. (2002). Stories and social networks. Advances in Conciousness Research, 46, 305-322.

Santos, F. (2009), A positive theory of social entrepreneurship, INSEAD, Barcelona.

Scott, S. G., \& Bruce, R. A. (1994). Determinants of innovative behavior. A path model of individual innovation in the workplace. Academy of Management Journal, 37(3), 580-607.

Sezgi, F., \& Mair, J. (2010). To control or not control: A coordination perspective to scaling. In Scaling Social Impact: New Thinking (1st ed., 29-44). New York: Palgrave MacMillan.

Sharma, A. (2017). Antecendents of social entrepreneurs behaviors on scaling up of social enterprise impact. Journal of Asia Entrepreneurship \& Sustainability, 13(1), 28-50.

Smith, B. R., Knapp, J., Barr, T. F., Stevens, C. E., \& Cannatelli, B. L. (2010). Social enterprises and the timing of conception: Organizational identity tension, management, and marketing. Journal of Nonprofit \& Public Sector Marketing, 22(2), 108-134.

Social Enterprise National Survey. (2015) Retrieved from www.se.mymagic.my. On 15 February 2018.

Sorenson, M. (2007). How smart is smart money? An empirical two-sided matching model of venture capital. Journal of Finance, 62, 2725-2762.

Stumbitz, B. (2013). Social entrepreneurship shaped by the life course: a case study of older social entrepreneurs in the UK.

Tukamushaba, E., Orobia, L. \& George, B. (2011). Development of a conceptual model to understand international social entrepreneurship and its application in the Ugandan context. Journal of International Entrepreneurship 9(4), 282-298.

Venkatraman, N. (1989). The concept of fit in strategy research: Toward verbal and statistical correspondence. Academy of management review, 423-444.

Weber, C., Kroger, A., \& Lambrich, K. (2012). Scaling social enterprise: A theoretically grounded framework. Frontiers of Entrepreneurship Research, 32(19), 1-15.

Weerawardena, J., \& Mort, G. S. (2006). Investigating social entrepreneurship: a multidimensional model. Journal of World Business, 41, 21-35.

Zahra, S. A., Gedajlovic, E., Newbaum, D. O., \& Shulman, J. M. (2009). A typology of social enterprise: motives, search processes and ethical challenges. Journal of Business Venturing, 24, 519-532.

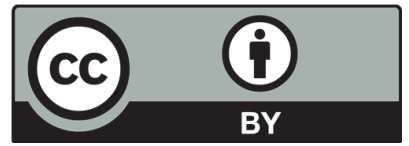

(C) 2019 by the authors; licensee Growing Science, Canada. This is an open access article distributed under the terms and conditions of the Creative Commons Attribution (CC-BY) license (http://creativecommons.org/licenses/by/4.0/). 